PERM JOURNAL OF PETROLEUM AND MINING ENGINEERING

ВЕСТНИК ПНИПУ. ГЕОЛОГИЯ. НЕФТЕГАЗОВОЕ И ГОРНОЕ ДЕЛО

ISSN 2224-9923

Volume/ ToM 16 №2 2017

http://vestnik-pstu.ru/geo/

УДК 331.453

Article / Статья

(C) PNRPU / ПНИПУ, 2017

\title{
EVALUATION OF JOINT EFFECT OF FACTORS OF SMALL INTENSITY OF PRODUCTION ENVIRONMENT AND LABOR PROCESS ON WORK ABILITY AND ERROR OF ACTION OF OPERATORS OF HIGH-TECH ENERGY COMPLEXES
}

\author{
Nina L. Vishnevskaia, Larisa V. Plakhova, Pavel Polednak ${ }^{1}$, Ales Bernatic ${ }^{1}$ \\ Perm National Research Polytechnic University (29 Komsomolskii av., Perm, 614990, Russian Federation) \\ ${ }^{1}$ Technical University of Ostrava (13 Liumirova st., Ostrava, 70030, Czech Republic)

\section{ОЦЕНКА СОЧЕТАННОГО ВЛИЯНИЯ ФАКТОРОВ МАЛОЙ ИНТЕНСИВНОСТИ ПРОИЗВОДСТВЕННОЙ СРЕДЫ И ТРУДОВОГО ПРОЦЕССА НА РАБОТОСПОСОБНОСТЬ И ОШИБОЧНОСТЬ ДЕЙСТВИЙ ОПЕРАТОРОВ ВЫСОКОТЕХНОЛОГИЧНЫХ ЭНЕРГЕТИЧЕСКИХ КОМПЛЕКСОВ}

\section{Н.Л. Вишневская, Л.В. Плахова, П. Поледняк ${ }^{1}$, А. Бернатик ${ }^{1}$}

Пермский национальный исследовательский политехнический университет (614990, Россия, г. Пермь, Комсомольский пр-т, 29) ${ }^{1}$ Остравский технический университет (70030, Чехия, Острава Витковице, ул. Люмирова, 13)

Получена / Received: 23.03.2017. Принята / Accepted: 10.05.2017. Опубликована / Published: 30.06.2017

Key words:

tension of labor process, factors of low intensity, work ability of operators, energy complexes, professional disease, preventive regimes of work and rest.
Ключевые слова: напряженность трудового процесса, факторы малой интенсивности, работоспособность операторов, энергетические комплексы, профессиональное заболевание, профилактические режимы труда и отдыха.

\begin{abstract}
Increase in complexity and speed of production processes puts forward strong requirements for accuracy of operators' actions, quick decision-making in performance of management functions. Statistical analysis of data on the oil refining industry showed that a refinery with a capacity of 10 million tons of oil per year loses in average $\$ 4$ million only from accidents caused by operator's errors. Around $40 \%$ of accidents and incidents occur due to operator's errors. Reasons for such errors are related to personal qualities, lack of education, training, as well as to factors of low intensity of production environment. A complex of factors of low intensity can lead to hidden up to a certain time "compensated" homeostatic disturbances or modify harmful effect with demonstration of inadequate reactions. The article presents results of study of operators of central control room of two technological departments of high-tech and hazard production (oil and gas) complex to assess combined influence of factors of low intensity of production environment and labor process on work ability and error of actions during labor process. Studies have showed that a long intense functional load on body's systems with influence of factors of low intensity of production environment and labor process lead to development of fatigue and increased tension that operators suffer during day and night shifts. Significant tension of sensory and intellectual systems of the organism with fatigue determines high physiological cost of labor of high-tech production operators. That indicates a need to develop preventive innovative methods to correct a physiological state of operators to improve their performance and take errors off labor, which reduce risk of physical illness.
\end{abstract}

Увеличение сложности и скорости производственных процессов выдвигает повышенные требования к точности действий операторов, быстроте принятия решений в осуществлении управленческих функций. Статистический анализ данных по нефтеперерабатывающей отрасли показал, что нефтеперерабатывающий завод мощностью 10 млн т нефти в год теряет только от аварий из-за ошибок операторов в среднем 4 млн долл. в год, 40 \% аварий и инцидентов происходят непосредственно из-за ошибок операторов. Причины таких ошибок связаны с личностными качествами человека, недостатками обучения, тренировки, а также с факторами малой интенсивности производственной среды. Комплекс факторов малой интенсивности может приводить к скрытым до определенного времени «компенсированным» нарушениям гомеостаза или модифицировать вредное действие с проявлением неадекватных реакций. В статье приведены результаты исследования операторов центрального пульта управления двух технологических отделений высокотехнологичного и опасного производственного (нефтегазового) комплекса для оценки сочетанного влияния факторов малой интенсивности производственной среды и трудового процесса на работоспособность и ошибочность действий в ходе трудового процесса. Исследования показали, что длительная напряженная функшиональная нагрузка на системы организма на фоне воздействия факторов малой интенсивности производственной среды и трудового процесса приводит к развитию утомления и повышенной напряженности у операторов в дневные и ночные смены. Значительное напряжение сенсорных и интеллектуальных систем организма на фоне выраженного утомления определяет высокую физиологическую стоимость труда операторов высокотехнологичного производства. Это свидетельствует о необходимости разработки профилактических инновационных методов коррекции физиологического состояния операторов для повышения их работоспособности и безошибочности труда, позволяющих снизить риск возникновения соматических нарушений здоровья.

\footnotetext{
Nina L. Vishnevskaia (Author ID in Scopus: 6507504628) - Doctor of Medicine, Professor at the Department of Life Safety (mob. tel.: +007 908 273 01 20, e-mail: charry14@mail.ru). Larisa V. Plakhova (Author ID in Scopus: 6507109246) - PhD in Biology, Associate Professor at the Department of Life Safety (mob. tel.: +007 952 336 44 80, e-mail: larisa-2570@mail.ru). The contact person for correspondence.

Pavel Polednak (Author ID in Scopus: 51562178900) - Professor, Dean of the Faculty of Safety Engineering (tel.: 842 059 732 28 03, e-mail: pave.polednak@vsb.cz) Ales Bernatic (Author ID in Scopus: 13205532400) - Professor, Deputy dean of the Faculty of International Relations (tel.: 8420603565912 , e-mail: ales.bernatic@vsb.cz).

Вишневская Нина Леонидовна - доктор медицинских наук, профессор кафедры безопасности жизнедеятельности (моб. тел.: +007 908 273 0120 , е-таil: charry14@mail.ru). Плахова Лариса Викторовна - кандидат биологических наук, доцент кафедры безопасности жизнедеятельности (моб. тел.: +007 952 336 4480 , e-mail: larisa-2570@mail.ru). Контактное лицо для переписки.

Поледняк Павел - профессор, декан факультета технической безопасности (тел.: 842059732 28 03, e-mail: pave.polednak@vsb.cz).

Бернатик Алес - профессор, заместитель декана факультета международных отношений (тел.: 842060 356 5912, e-mail: ales.bernatic@vsb.cz).
} 


\section{Introduction}

Increase in complexity and speed of industrial processes causes strong requirements for accuracy of actions that an operator does and quick decision-making in management [1-5]. The degree of responsibility for actions is increased greatly, because operator's mistake can lead to disruption of the entire system humantechnology-environment, create an emergency situation with a threat to people's lives. According to the statistics $70 \%$ of world accidents and incidents at hazard industrial sites are caused by operators' faults [5-9].

According to Honeywell, a typical oil refinery with a capacity of 10 million tons of oil a year loses around \$ 4 million per year from accidents only due to operator's errors, $40 \%$ of accidents and incidents occur directly due to operator's errors [10-14].

Analysis of causes of such errors showed that most of them are related to qualities of a person, lack of education, training. But quite often the issue of influence of a complex of factors of the low-intensity production environment is ignored. At the same time, a complex of low intensity factors can lead to "compensated" disturbances of homeostasis hidden up to a certain time or modify a harmful effect and cause inadequate reactions [10-13]. Therefore, screening for characteristics and indicators that allow to identify the negative impact of low-intensity factors and ensure optimization of efficiency and prevention of error actions of personnel is considered as a promising one $[11,12,14-18]$.

It is known that the factors of low intensity should be considered those with concentration levels are much lower than permissible and do not cause firm biological changes in case of isolated action. However, a complex effect in the conditions of long time (12-hour shifts) can lead to negative results that are not so known. At the same time, work features can contribute to a change in a functional state of an organism, tension of adaptation mechanisms, formation and development of diseases that have complex multifactorial etiology such as hypertension, disorders of nonspecific resistance, metabolism, musculoskeletal system and formation of diseases caused by a specialty [19-23].

The purpose of the research is to evaluate joint effect of factors of low intensity of the production environment and labor process on work ability and error of action of operators of high-tech energy complexes.

The object of the research were operators of a central control room (CCR) of two technological departments of high-tech and dangerous industrial complex.

\section{Results and discussion}

Personnel of CCR is represented mainly (almost $80 \%$ ) by young people (up to 25 years) and only $3 \%$ of employees belong to a category who are over 50.

Among the factors of low intensity affecting operators of a high-tech production complex, it is necessary to note sanitary and hygienic state of the thermal environment with low relative humidity of $30 \%$; long impact of low levels of electromagnetic fields of radio frequencies on personnel; an unfavorable state of an aeroionic composition of the air with predominance of average aeroions of positive charge [1-3].

\section{Assessment of work conditions of operators in terms of ergonomics and aesthetics}

Since the main activity of operators is related to remote monitoring of a technological process, assessment of ergonomics provided and placement convenience of workplace is important especially. The analysis showed that up to $30 \%$ of work places did not meet the anthropometric parameters of workers. Long stay in a forced sitting position contributes to increase in load on the musculoskeletal apparatus and development of fatigue especially when recently the duration of shifts of operators of high-tech production complexes is increased up to 12 hours. Performed ergonomics assessment of work conditions revealed a number of disturbances in a composition of workplaces, balance of static and dynamic parameters and placement of video 
equipment. There are $30 \%$ of workplaces incompatible to anthropometric parameters of operators, lack of adjustment in height and angle of inclination, disturbance of placement of control elements, borders of reach zones.

The aesthetic characteristic of the production environment has shown that color and composition solutions of the production environment and equipment do not contribute to optimization of work conditions and prevention of intensity of the labor process.

Thus, a complex of factors of low intensity (sanitary hygienic, ergonomic and aesthetic), affecting the operators of the CCR was revealed. The regime of work of studied personell should also be classified as unfavorable.

\section{Analysis of the impact of low-intensity factors on health of operators}

Hours-long shifts with night duty lead to disruption of habitual biorhythms (sleep, wakefulness, working capacity), changes in metabolic processes and hormonal metabolism, contribute to a more rapid development of fatigue $[1,3,4,6,7]$. Most often employees complain for drowsiness. The impact of shift work on sleep disorder is more often seen in employees that have small amount of work experience. The most tough demonstration of circadian desynchrony can be decrease in efficiency, attention but also that could be the background for development of pathological states, in particular, diseases of a cardiovascular system and oncopathology $[6,18,19]$. According to the International Agency for the Study of Cancer, night shift work belongs to the category of probable carcinogenic factors (group 2A) [24-27].

Thus, CCR operators are exposed to factors of low intensity of production environment and labor process, which creates objective conditions for development of hypodynamia, monotonies, fatigue, desynchronosis and subsequent formation of professionally conditioned pathology.

\section{Assessment of key health indicators of operators in the dynamics of shifts}

We performed an assessment of organism functioning in dynamics of work shifts and conducted a study of health status of personnel by age groups (Fig.).

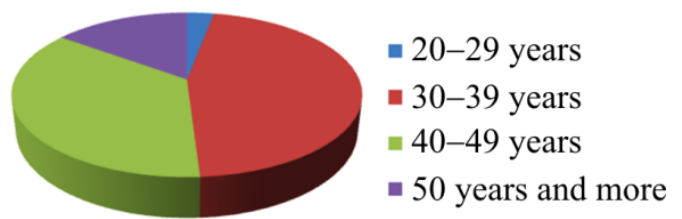

Fig. Age structure of CCR personnel

Health indicators of personnel should be consider as an integral indicator of the assessment of influence of factors in the production environment.

Dynamics of health indicators of personnel over a five-year period indicates an increase in heart disease, varicose veins and diseases of analyzers such as an eye and nose. According to medical examination material it was determined that only $12.1 \%$ of the total number of people can be classified as absolutely healthy, even though the age of composition of CCR personnel, as noted above, can be characterized as close to the optimal one (see Fig. 1). Up to $70 \%$ of the operators were overweight, which indicates a violation of metabolic processes.

An analysis of available information of contingent studied most often showed deviations from physiological norm for a cardiovascular system, vision organs, nose; varicose disease of lower extremities was recorded. Frequency of heart disease was 36.56 per 100 examined, eye diseases -29.8 per 100 , diseases of a nasal cavity -12.43 , varicose disease of lower extremities - 12,56 (Table 1).

Table 1

Frequency of registered diseases per 100 examined in different age groups

\begin{tabular}{|l|c|c|c|c|}
\hline $\begin{array}{c}\text { Age group, } \\
\text { years }\end{array}$ & $\begin{array}{c}\text { Frequency } \\
\text { of cardiovascular diseases }\end{array}$ & $\begin{array}{c}\text { Frequency of diseases } \\
\text { of vision organs }\end{array}$ & $\begin{array}{c}\text { Frequency } \\
\text { of varicose veins }\end{array}$ & 8.50 \\
\hline $30-39$ & 33.30 & 23.30 & 6.70 & 10.50 \\
\hline $40-49$ & 37.90 & 27.60 & 13.80 & 18.70 \\
\hline 50 and older & 38.50 & 38.50 & 16.80 & $12.56 \pm 5.40$ \\
\hline Average value & $36.56 \pm 2.84$ & $29.8 \pm 7.83$ & $12.43 \pm 5.18$ \\
\hline
\end{tabular}


It was noted in a number of studies that body mass index is significantly higher for persons working on night shifts or with long shift $(p<0.001)$ [28, 29]. The inverse relationship between lack of sleep and body mass index was revealed. The sleep duration of workers with obesity was 18 minutes less each day $(p<0.05)$ than their colleagues with normal body weight [24, 28]. To ensure work ability, reliability and efficiency of operators at work the problem of assessing the functional state is fundamental. Quantitative assessment of the parameters allows us not only to estimate, but also to predict the level and volume of functional reserves in professional activity [29-32].

During the research performed a functional state was determined by the time of simple and complex sensorimotor reactions to light and sound stimuli, reactions to a moving object, critical frequency of light flashes, stability of attention and error in actions. The data obtained were estimated by methods of mathematical statistics with use of an application package Statistica v. 6.0. The probability of a null hypothesis $(p)$ was determined using the Mann-Whitney criteria and Student's tcriterion depending on the normality of sample distribution.

The studies were conducted during shifts (beginning, end) in two departments and two age groups such as up to $35\left(1^{\text {st }}\right)$ and after 35 years $\left(2^{\text {nd }}\right)$.

The rate of a simple sensorimotor reaction in all age groups of people working in day shifts increased by the end of the work shift, but worsened during the night shifts (Table 2).

Table 2

Psychophysiological characteristics of operators during day and night shifts

\begin{tabular}{|c|c|c|c|c|c|c|c|}
\hline \multirow{3}{*}{ Age group } & \multirow{2}{*}{$\begin{array}{c}\text { Working shift } \\
\text { period }\end{array}$} & \multirow{2}{*}{$\begin{array}{c}\text { Visual-motor } \\
\text { reaction, ms }\end{array}$} & \multirow{2}{*}{$\begin{array}{c}\text { Hearing-motor } \\
\text { reaction, ms }\end{array}$} & \multicolumn{2}{|c|}{$\begin{array}{c}\text { Differentiation } \\
\text { and noise stability }\end{array}$} & \multicolumn{2}{|c|}{$\begin{array}{c}\text { Stability of attention } \\
\text { and error in actions }\end{array}$} \\
\cline { 5 - 8 } & & & & total volume & $\%$ & total volume & number of errors \\
\hline \multirow{2}{*}{$1^{\text {st }}$} & Beginning & $362 \pm 2$ & $206 \pm 3$ & $2308 \pm 7$ & 12 & $406 \pm 2$ & 6 \\
\cline { 5 - 9 } & End & $296 \pm 1.5$ & $196 \pm 2$ & $2048 \pm 6$ & 8 & $496 \pm 4$ & 7.7 \\
\hline \multirow{2}{*}{$2^{\text {nd }}$} & Beginning & $488 \pm 2$ & $208 \pm 2.5$ & $3801 \pm 10$ & 9 & $380 \pm 4$ & 4 \\
\cline { 2 - 8 } & End & $542 \pm 3$ & $286 \pm 2$ & $2794 \pm 8$ & 9.7 & $458 \pm 3$ & 6.7 \\
\hline \multirow{2}{*}{$3^{\text {rd }}$} & Beginning & $303 \pm 2$ & $192 \pm 2.5$ & $2200 \pm 10$ & 9 & $570 \pm 4$ & 5 \\
\cline { 2 - 8 } & End & $267 \pm 1$ & $191 \pm 2$ & $1601 \pm 5$ & 10 & $621 \pm 5$ & 9 \\
\hline \multirow{2}{*}{$4^{\text {th }}$} & Beginning & $347 \pm 2$ & $181 \pm 1.5$ & $3360 \pm 9$ & 6 & $424 \pm 2$ & 2.5 \\
\cline { 2 - 8 } & End & $514 \pm 3$ & $198 \pm 3$ & $2478 \pm 7$ & 14.5 & $450 \pm 3$ & 4.5 \\
\hline
\end{tabular}

Change in the state of operators in the end of the work shift can be traced by the reaction of stability of attention and error in actions.

As it is shown in the Table 2, speed of work performance by the end of the shift grows in both age groups by $10-15 \%$, which indicates the effect of training principles. Neverthelles, at the end of the work shift stability of attention and the number of errors increase, which indicates fatigue caused by hypodynamia that is almost twice higher in the first age group of up to 35 years. Thus, a high level of neuro emotional tension of personnel and increase in speed of work performance is accompanied by an increase in errors in actions, which proves that functioning of body regulatory systems was changed, a central nervous system and analyzers are loaded, and objectively indicates the onset of fatigue. Important results were obtained in evaluation of the noise resistance reaction. Attention and efficiency at the beginning of work shifts against the background of visual and auditory noise were fairly steady. By the end of the shift attention in surveyed groups was decreased as by $12 \%$ for the first group and more than by $20 \%$ for the second group. At the same time, the operator's error in actions with the background of visual and sound noise in the first group was 12-18 $\%$ higher and almost twice as high in the second group. That reaction indicates the onset of a change in fatigue and the need to activate physiological reserves of the body for the fulfillment of professional duties by the workers.

Results of the personnel survey confirm the established class of work conditions in terms of 
indicators of intensity of the labor process. It is established that on the background of nervous emotional, sensory tension of personnel the number of errors in actions increases at the end of shifts when personnel performs specific tasks that reveal functional reserves of an organism, which allows to talk about the signs of monotony.

The research conducted showed that during work operations CCR personnel suffer fatigue by the end of the work shift. Nevertheless, strongwilled efforts, attention, concentration, purposefulness of actions, operators control a technological process adequately.

At the same time, reactions caused by fatigue among the whole team of operators testify the need to justify and develop measures to prevent development of fatigue, hypokinesia and monotony during work shifts.

Thus, development of fatigue during shifts leads to a significant decrease in the excitability of the central nervous system (thresholds of perception increase), decrease in the quality of cognitive processes and difficulty in heuristic thinking. Reliability and efficiency of operators' activity is reduced, but the probability of missing significant signals increases, especially in tracking and monitoring regimes. The state of health and mood is deteriorating, asthenovegetative state is developed. There is an increased number of errors noted by the end of the shift.

Performed studies have shown that during the day and night shifts operators suffer fatigue. At the same time, physiological indicators of the organism's activity and parameters of assessment of activity of sensory systems indicate significant loads, but operators activate attention, focus on a task and control the technological process adequately. Consequently, it should be considered that the physiological value of the labor process of operators is quite high and the need for the optional activation of physiological reserves of the organism to perform professional tasks significantly increases the intensity of labor.

\section{Conclusion}

Evaluation of factors of the production environment and the labor process at workplaces of operators at CCR of high-tech energy complexes allowed to classify them as a group of low-intensity factors.

Health as an integral indicator shows the generation of a number of negative states of operators including cardiovascular, sensory systems and metabolic syndrome.

Long tough functional load on body systems against the backdrop of the influence of factors of low intensity of the production environment and labor process lead to the development of fatigue and increased tension that operators suffer during day and night shifts.

Significant tension of sensory and intellectual systems of the organism against the backdrop of strong fatigue determines the high physiological cost of labor of high-tech production operators. That indicates the need to develop preventive innovative methods for correction of physiological state of operators to improve their ability to work and error-free work that can reduce the risk of somatic disorders of health.

\section{References}

1. Chernyi K.A. Problema otsenki i vzaimosviazi aerozol'nogo zagriazneniia i aeroionnogo sostava vozdukha rabochei zony [The problem of assessment and interrelation of aerosol pollution and aeroionic composition of air in the work area]. Abstract of Doctor's degree dissertation. Saint Petersburg, 2013, 43 p.

2. Chernyi K.A., Khramov A.V. Sposob snizheniia urovnia napriazhennosti truda i professional'nogo stressa putem korrektsii ionnogo sostava vozdukha rabochei zony [Method for reducing the level of labor intensity and occupational stress by correcting the ion composition of the air in the work area]. Valeologiia, 2012, no.1, pp.64-69.
3. Chernyi K.A. Sposob otsenki parametrov sverkhtonkoi fraktsii aerozol'nykh chastits $\mathrm{v}$ vozdukhe [Method for estimating the parameters of the hyperfine fraction of aerosol particles in air]. Bezopasnost' $v$ tekhnosfere, 2012, no.2, pp.3-6.

4. Bakirov A.B. Problemy sokhraneniia zdorov'ia trudosposobnogo naseleniia $\mathrm{V}$ respublike Bashkortostan [Problems of preserving the health of the able-bodied population in the Republic of Bashkortostan]. Meditsina truda i ekologiia cheloveka, 2015, no.1, pp.4-5.

5. Valeeva E.T., Karimova L.K., Gimranova G.G. Professional'naia i proizvodstvenno obuslovlennaia 
patologiia u rabotaiushchikh $\mathrm{v}$ sovremennykh neftekhimicheskikh proizvodstvakh [Professional and production conditioned pathology in workers in modern petrochemical industries]. Agroekologicheskaia bezopasnost' v usloviiakh tekhnogeneza. Mezhdunarodnyi simpozium. Sbornik nauchnykh dokladov. Kazan', 2006, part 1, pp.129-132.

6. Blaginin A.A. Nadezhnost' professional'noi deiatel'nosti operatorov slozhnykh ergaticheskikh sistem [Reliability of professional activity of operators of complex ergatic systems]. Saint Petersburg, Leningradskii gosudarstvennyi universitet im. A.S. Pushkina, 2006, 144 p.

7. Professional'nyi risk dlia zdorov'ia rabotnikov [Professional health risk for workers]. Rukovodstvo. Eds. N.F. Izmerov, E.I. Denisov. Moscow, Trovant, 2003, 448 p.

8. Shibkova D.Z., Ovchinnikova A.V. Effekty vozdeistviia elektromagnitnykh izluchenii na raznykh urovniakh organizatsii biologicheskikh sistem [Effects of electromagnetic radiation at different levels of organization of biological systems]. Uspekhi sovremennogo estestvoznaniia, 2015, no.5, pp.156-157.

9. Goode J.H. Are pilots at risk of accidents due to fatigue? Journal of Safety Research, 2003, vol.34, no.3, pp.309-313. DOI: 10.1016/S0022-4375(03)00033-1

10. Koskinen H., Harma M., Kauppinen T., Tenkanen L. Shift work, occupational noise and physical workload with ensuing development of blood pressure and their joint effect on the risk of coronary heart disease. Scandinavian Journal of Work, Environment \& Health, 2008, 33 (6), pp.425-434. DOI: 10.5271/sjweh.1170

11. Copertaro A., Bracci M., Barbaresi M., Santarelli L. Importanza dellacirconferenza vita per la diagnosi di sindromemetabolicae per la valutazione del rischiocardiovascolareneilavoratori turnisti (Role of waist circumference in the diagnosis of metabolic syndrome and assessment of cardiovascular risk in shift workers). La MedicinadelLavoro, 2008, 99 (6), 444-453.

12. Ishizaki M., Nakagawa H., Morikawa Y., Honda R., Yamada Y., Kawakami N. Influence of job strain on changes in body mass index and waist circumference: 6-year longitudinal study. Scandinavian Journal of Work, Environment \& Health, 2008, 34 (4), pp.288-296. DOI: 10.5271/sjweh.1267

13. Karlsson B., Knutsson A., Lindahl B. Is there an association between shift work and having a metabolic syndrome? Results from a population based study of 27,485 people. Occupational and Environmental Medicin, 2001, 58 (11), pp.747-752. DOI: 10.1136/oem.58.11.747

14. Macdonald E.B. Occupational medicine in Europe: Evolution of the profession. WHO/ECEH. Bilthoven, 1999, p. 31.

15. Roach G.D., Rodgers M., Dawson D. Circadian adaptation of aircrew to transmeridian flight. Aviat. Space Environ. Med., 2002, vol. 73, pp.1153-1160.
16. Vishnevskaya N.L., Plahova L.V.The innovative security model of the personnel for hazardous production facilities and psychological problems. International journal of applied and fundamental research, 2013, no.2, pp.49.

17. Izmerov N.F., Bukhtiiarov I.V., Denisov E.I. Otsenka professional'nykh riskov dlia zdorov'ia $\mathrm{v}$ sisteme dokazatel'noi meditsiny [Assessment of occupational health risks in the system of evidence-based medicine]. Voprosy shkol'noi i universitetskoi meditsiny i zdorov'ia, 2016, vol.1, pp.14-20.

18. Maslov N. B., Bloshchinskii I.A., Galushkina E.A., Rogovanov D.Iu. Kontseptual'nye podkhody $\mathrm{k}$ otsenke funktsional'nogo sostoianiia spetsialistov $\mathrm{v}$ protsesse ikh professional'noi deiatel'nosti [Conceptual approaches to the assessment of the functional state of specialists in the process of their professional activities]. Ekologiia cheloveka, 2012, no.4, pp.16-24.

19. Vasin A.L. Razrabotka sistemy obobshchennykh pokazatelei dlia kharakteristiki adaptatsionnykh protsessov $\mathrm{v}$ organizme pri khronicheskom vozdeistvii elektromagnitnykh polei radiochastot $(\mathrm{k}$ probleme normirovaniia fizicheskikh faktorov) [Development of a system of generalized indicators for the characterization of adaptation processes in the body with chronic exposure to electromagnetic fields of radio frequencies: to the problem of normalizing physical factors]. Ph.D. thesis. Moscow, 2008. 166 p.

20. Denisov E.I., Chesalin P.V. Dokazatel'nost' v meditsine truda: printsipy i otsenka sviazi narushenii zdorov'ia s rabotoi [Evidence in the medicine of work: principles and assessment of the relationship between health disorders and work]. Meditsina truda $i$ promyshlennaia ekologiia, 2006, no.11, pp.6-14.

21. Vishnevskaia N.L., Plakhova L.V., Chernyi K.A. Metodicheskie podkhody $\mathrm{k}$ otsenke uslovii i opredeleniiu napriazhennosti truda operatorov vysokotekhnologichnykh opasnykh proizvodstv [Methodical approaches to the assessment of conditions and the definition of labor intensity of operators of high-technology hazardous industries]. Zdorov'e $i$ obrazovanie v XXI veke, 2016, vol.18, no.8, pp.69-71.

22. Harma M., Kecklund G. Shift work and health how to proceed? Scand. J. Work Environ. Health, 2010, 36 (2), pp.81-84. DOI: $10.2307 / 40967834$

23. Painting, firefighting, and shift work. IARC monographs on the evaluation of carcinogenic risks to humans. Lyon, IARC, 2010, vol.98, 818 p.

24. Arendt J. Shift work: coping with the biological clock. Occup. Med., 2010, 60 (1), pp.10-20. DOI: 10.1093/occmed/kqp162

25. Lowden A., Moreno C., Holmback U., Lennernas M., Tucker P. Eating and shift work - effects on habits, metabolism and performance. Scand. J. Work Environ. Health, 2010, 36 (2), pp.150-162. DOI: 10.2307/40967841 
26. Sallinen M., Kecklund G. Shift work, sleep, and sleepiness - differences between shift schedules and systems. Scand. J. Work Environ. Health, 2010, 36 (2), pp.121-133. DOI: $10.2307 / 40967838$

27. Eriksen C.A., Kecklund G. Sleep, sleepiness and health complaints in police officers: the effects of a flexible shift system. Ind. Health, 2007, 45, pp.279-288. DOI: $10.2486 /$ indhealth.45.279

28. Tucker Ph., Folkard S., Ansiau D., Marquie J.-C. The effects of age and shiftwork on perceived sleep problems: results from the VISAT-combined longitudinal and cross-sectional study. Journal of occupational and environmental medicine, 2010, 52 (4), pp.392-398. DOI: 10.1097/JOM.0b013e3181d8d9e4
29. Asaoka S., Namba K., Tsuiki S., Komada Y., Inoue Y. Excessive daytime sleepiness among Japanese public transportation drivers engaged in shiftwork. Journal of occupational and environmental medicine 2010, 52, pp.813-818. DOI: 10.1097/JOM.0b013e3181 ea5a67

30. Viitasalo K., Kuosma E., Laitinen J., Harma M. Effects of shift rotation and the flexibility of a shift system on daytime alertness and cardiovascular risk factors. Scandinavian Journal of Work, Environment \& Health, 2008, 34 (3), pp.198-205. DOI: 10.5271/sjweh.1228

31. Puttonen S., Harma M., Hublin C. Shift work and cardiovascular disease - pathways from circadian stress to morbidity. Scandinavian Journal of Work, Environment \& Health, 2010, 36 (2), pp.96-108. DOI: 10.2307/40967836

\section{Библиографический список}

1. Черный К.А. Проблема оценки и взаимосвязи аэрозольного загрязнения и аэроионного состава воздуха рабочей зоны: автореф. дис. ... д-ра техн. наук / Балт. гос. техн. ун-т (BОЕНМЕХ) им. Ф.Д. Устинова. СПб., 2013. - 43 c.

2. Черный К.А., Храмов А.В. Способ снижения уровня напряженности труда и профессионального стресса путем коррекции ионного состава воздуха рабочей зоны // Валеология. - 2012. - № 1. - С. 64-69.

3. Черный К.А. Способ оценки параметров сверхтонкой фракции аэрозольных частиц в воздухе // Безопасность в техносфере. - 2012. - № 2. - С. 3-6.

4. Бакиров А.Б. Проблемы сохранения здоровья трудоспособного населения в республике Башкортостан // Медицина труда и экология человека. - 2015. - № 1. - С. 4-5.

5. Валеева Э.Т., Каримова Л.К., Гимранова Г.Г. Профессиональная и производственно обусловленная патология у работающих в современных нефтехимических производствах // Агроэкологическая безопасность в условиях техногенеза: междунар. симп.: сб. науч. докл. - Казань, 2006. - Ч. 1. - С. 129-132.

6. Благинин А.А. Надежность профессиональной деятельности операторов сложных эргатических систем / Ленингр. гос. ун-т им. А.С. Пушкина. - СПб., 2006. -144 c.

7. Профессиональный риск для здоровья работников: руководство / под ред. Н.Ф. Измерова, Э.И. Денисова. М.: Тровант, 2003. $-448 \mathrm{c}$.

8. Шибкова Д.З., Овчинникова А.В. Эффекты воздействия электромагнитных излучений на разных уровнях организации биологических систем // Успехи современного естествознания. - 2015. - № 5. - С. 156-157.

9. Goode J.H. Are pilots at risk of accidents due to fatigue? // Journal of Safety Research. - 2003. - Vol. 34, № 3. P. 309-313. DOI: 10.1016/S0022-4375(03)00033-1

10. Shift work, occupational noise and physical workload with ensuing development of blood pressure and their joint effect on the risk of coronary heart disease / H. Koskinen, M. Harma, T. Kauppinen, L. Tenkanen // Scandinavian Journal of Work, Environment \& Health. 2008. - 33 (6). - P. 425-434. DOI: 10.5271/sjweh. 1170

11. Importanza dellacirconferenza vita per la diagnosi di sindromemetabolicae per la valutazione del rischiocardiovascolareneilavoratori turnisti (Role of waist circumference in the diagnosis of metabolic syndrome and assessment of cardiovascular risk in shift workers) / A. Copertaro, M. Bracci, M. Barbaresi, L. Santarelli // La MedicinadelLavoro. - 2008. - 99 (6). - P. 444-453.

12. Influence of job strain on changes in body mass index and waist circumference: 6-year longitudinal study / M. Ishizaki, H. Nakagawa, Y. Morikawa, R. Honda, Y. Yamada, N. Kawakami // Scandinavian Journal of Work, Environment \& Health. - 2008. - 34 (4). P. 288-296. DOI: 10.5271/sjweh. 1267

13. Karlsson B., Knutsson A., Lindahl B. Is there an association between shift work and having a metabolic syndrome? Results from a population based study of 27,485 people // Occupational and Environmental Medicine. - 2001. - 58 (11). - P. 747-752. DOI: $10.1136 /$ oem.58.11.747

14. Macdonald E.B. Occupational medicine in Europe: Evolution of the profession / WHO/ECEH. - Bilthoven, 1999. - P. 31.

15. Roach G.D., Rodgers M., Dawson D. Circadian adaptation of aircrew to transmeridian flight // Aviat. Space Environ. Med. - 2002. - Vol. 73. - P. 1153-1160.

16. Vishnevskaya N.L., Plahova L.V. The innovative security model of the personnel for hazardous production facilities and psychological problems // International Journal of Applied and Fundamental Research. - 2013. № 2. - С. 49.

17. Измеров Н.Ф., Бухтияров И.В., Денисов Э.И. Оценка профессиональных рисков для здоровья в системе доказательной медицины // Вопросы 
школьной и университетской медицины и здоровья. 2016. - Т. 1. - С. 14-20.

18. Концептуальные подходы к оценке функционального состояния специалистов в процессе их профессиональной деятельности / Н.Б. Маслов, И.А. Блощинский, Е.А. Галушкина, Д.Ю. Рогованов // Экология человека. - 2012. - № 4. - С. 16-24.

19. Васин А.Л. Разработка системы обобщенных показателей для характеристики адаптационных процессов в организме при хроническом воздействии электромагнитных полей радиочастот (к проблеме нормирования физических факторов): дис. ... канд. биол. наук / Моск. гос. ун-т им. Ломоносова. - М., 2008.

20. Денисов Э.И., Чесалин П.В. Доказательность в медицине труда: принципы и оценка связи нарушений здоровья с работой // Медицина труда и промышленная экология. - 2006. - № 11. - С. 6-14.

21. Вишневская Н.Л., Плахова Л.В., Черный К.А. Методические подходы к оценке условий и определению напряженности труда операторов высокотехнологичных опасных производств // Здоровье и образование в XXI веке. - 2016. - Т. 18, № 8. - С. 69-71.

22. Harma M., Kecklund G. Shift work and health how to proceed? // Scand. J. Work Environ. Health. 2010. - 36 (2). - P. 81-84. DOI: 10.2307/40967834

23. Painting, firefighting, and shift work: IARC monographs on the evaluation of carcinogenic risks to humans. - Lyon: IARC, 2010. - Vol. 98. - 818 p.

24. Arendt J. Shift work: coping with the biological clock // Occup. Med. - 2010. - 60 (1). - P. 10-20. DOI: 10.1093/occmed/kqp162
25. Eating and shift work - effects on habits, metabolism and performance / A. Lowden, C. Moreno, U. Holmback, M. Lennernas, P. Tucker // Scand. J. Work Environ. Health. 2010. - 36 (2). - P. 150-162. DOI: 10.2307/40967841

26. Sallinen M., Kecklund G. Shift work, sleep, and sleepiness - differences between shift schedules and systems // Scand. J. Work Environ. Health. - 2010. 36 (2). - P. 121-133. DOI: 10.2307/40967838

27. Eriksen C.A., Kecklund G. Sleep, sleepiness and health complaints in police officers: the effects of a flexible shift system // Ind. Health. - 2007. - 45 . - P. 279288. DOI: $10.2486 /$ indhealth.45.279

28. The effects of age and shiftwork on perceived sleep problems: results from the VISAT-combined longitudinal and cross-sectional study / Ph. Tucker, S. Folkard, D. Ansiau, J.-C. Marquie // Journal of occupational and environmental medicine. - 2010. - 52 (4). - P. 392-398. DOI: 10.1097/JOM.0b013e3181d8d9e4

29. Excessive daytime sleepiness among Japanese public transportation drivers engaged in shiftwork / S. Asaoka, K. Namba, S. Tsuiki, Y. Komada, Y. Inoue // Occup. Environ. Med. - 2010. - 52. - P. 813-818. DOI: 10.1097/JOM.0b013e3181 ea5a67

30. Effects of shift rotation and the flexibility of a shift system on daytime alertness and cardiovascular risk factors / K. Viitasalo, E. Kuosma, J. Laitinen, M. Harma // Scandinavian Journal of Work, Environment \& Health. 2008. - 34 (3). - P. 198-205. DOI: 10.5271/sjweh.1228

31. Puttonen S., Harma M., Hublin C. Shift work and cardiovascular disease - pathways from circadian stress to morbidity // Scandinavian Journal of Work, Environment \& Health. - 2010. - 36 (2). - P. 96-108. DOI: 10.2307/40967836

Please cite this article in English as:

Vishnevskaia N.L., Plakhova L.V., Polednak P., Bernatic A. Evaluation of joint effect of factors of small intensity of production environment and labor process on work ability and error of action of operators of high-tech energy complexes. Perm Journal of Petroleum and Mining Engineering, 2017, vol.16, no.2, pp.183-190. DOI: 10.15593/2224-9923/2017.2.9

Просьба ссылаться на эту статью в русскоязычных источниках следующим образом:

Оценка сочетанного влияния факторов малой интенсивности производственной среды и трудового процесса на работоспособность и ошибочность действий операторов высокотехнологичных энергетических комплексов / Н.Л. Вишневская, Л.В. Плахова, П. Поледняк, А. Бернатик // Вестник Пермского национального исследовательского политехнического университета. Геология. Нефтегазовое и горное дело. - 2017. - Т.16, №2. - C.183-190. DOI: 10.15593/2224-9923/2017.2.9 